\title{
The Enzyme Activities and Coenzyme Contents in the Reticulocytes of Rabbits
}

\author{
By
}

\section{Keiya Tada, Yasuhisa Watanabe and Tetsuro Fujiwara}

From the Department of Pediatrics, Faculty of Medicine, Tohoku University, Sendai; Director: Prof. Ts. Arakawa

(Received for publication, September 4, 1961)

It is generally believed that the reticulocyte appears after denucleation of the erythroblast and is a precursor of the erythrocyte. With a view to understanding an unique metabolism in the erythrocyte which is a "denucleated cell", we have investigated the difference in the activities of enzymes between the reticulocyte and the mature erythrocyte. For this purpose, the activities of some of enzymes and coenzymes in erythrocytes and reticulocytes were investigated in the rabbits.

\section{METHODS AND MATERIALS}

In three rabbits a marked reticulocytosis was caused by giving them daily subcutaneous injections of $25 \mathrm{mg}$ acetylphenylhydrazine (APH) in alcoholic $(50 \%)$ solution for a period of successive six days. Before the injection and on 2nd, 5th, and 14th day after completion of the injection, blood was withdrawn from the heart of the rabbits. The blood specimens were subjected to the determinations of erythrocyte count, of reticulocyte count and of hematocrit and then to the following analyses as mentioned below. By the way, the term "red cells" in this report means both mature erythrocytes and reticulocytes.

The activity of aldolase (AD) in red cells was determined by Sibley's method ${ }^{1)}$. The activity was expressed in the level per $\mathrm{ml}$ of red cells. Furthermore, the AD activity of single red cell was calculated as follows:

$$
\begin{array}{cc}
\mathrm{A} \times \mathrm{H} & \mathrm{A}: \text { Activity per } \mathrm{ml} \text { of red cells, } \\
\mathrm{R} \times 10^{-5} & \mathrm{H}: \text { Hematocrit }(\%), \\
& \mathrm{R}: \text { Red cell count per } \mathrm{mm}^{3} \text { of blood. }
\end{array}
$$

The activity of lactic dehydrogenase (LD) in red cells was determined by Hill's method.2) The activity was expressed in the level per ml of them. The LD activity of single red cell was calculated in the same way as that in the case of aldolase. 
The activity of glucose-6-phosphate dehydrogenase (G6PD) in red cells was determined by Zinkham's method. ${ }^{3)}$ The activity was expressed in the level per $\mathrm{ml}$ of red cells. The G6PD activity of single red cell was calculated in the same way as in the case of aldolase.

The content of reduced glutathione (GSH) in red cells was determined by Grunert's method.4)5) The content was expressed as $\mathrm{mg}$ per $100 \mathrm{ml}$ of red cells. The content per single red cell was calculated in the same way as in the case of aldolase.

The content of pyridine nucleotide (PN) in red cells was determined by Huff's method. ${ }^{6)}$ The content was expressed as $\gamma$ per ml of red cells. The content per single red cell was calculated in the same way as in the case of aldolase.

Glucose uptake test by red cells: Red cells separated from heparinized blood were three times washed with physiologic saline after the removal of buffy coat. The mixture, consisting of red cells $1 \mathrm{ml}$, plasma $0.5 \mathrm{ml}$, and isotonic saline-phosphate buffer $(\mathrm{pH} 7.3$, containing glucose of $300 \mathrm{mg} / \mathrm{dl}$ and water-soluble penicillin of 500 units $/ \mathrm{ml}$ ) $0.5 \mathrm{ml}$, was shaken at $37^{\circ} \mathrm{C}$. At intervals of 0 , one and two hours during the incubation the concentration of glucose in the mixture was determined in order to know the rate of utilization of glucose by red cells.

\section{RESULTS}

The results obtained were given in Table $\mathrm{I}$.

Reticulocyte count, which was below $10 \%$ before the APH injection, increased remarkably by the injection, showing a maximal rate (860 to $966 \%$ ) on 2nd day after completion of the injection and thereafter a gradual decrease to the rate of pre-injection stage (cf. Fig. 1).

The activity of $\mathrm{AD}$ in red cells increased in parallel with the degree of reticulocytosis. The activity of $\mathrm{AD}$ per single red cell showed a steeper peak than that per ml of red cells as was shown in Fig. 2. The activity of AD per single red cell before the APH injection was taken as the activity of AD per single mature erythrocyte, because the reticulocyte count was below $10 \%$ and negligible in number as compared with that of the mature erythrocytes. On the other hand the activity of $\mathrm{AD}$ per single red cell on the $2 \mathrm{nd}$ day after completion of the injection was considered as the activity of $\mathrm{AD}$ per single reticulocyte, because the reticulocyte count was over $950 \%$ and the count of mature erythrocytes was reduced to a negligible number as compared with that of reticulocytes. If the $\mathrm{AD}$ activity in single mature erythrocyte is compared with that in single reticulocyte, it may be said as will be seen from Fig. 2, that the reticulocyte has approximately 8 to 10 times higher activity of $\mathrm{AD}$ than the mature erythrocyte has.

The activity of LD in red cells increased in parallel with the degree of reticulocytosis. The activity of LD per single red cell showed a steeper peak 
Table I. The Enzyme Activities and Coenzyme Contents in Red Cells of Rabbits with APH Injection

\begin{tabular}{|c|c|c|c|c|c|}
\hline & \multirow{2}{*}{$\begin{array}{l}\text { No. of } \\
\text { rabbits }\end{array}$} & \multicolumn{4}{|c|}{ No. of examination* } \\
\hline & & I & II & $\mathbb{I I}$ & II \\
\hline $\begin{array}{c}\text { Reticulocytes } \\
\% \%\end{array}$ & $\begin{array}{l}1 \\
2 \\
3\end{array}$ & $\begin{array}{r}10 \\
10 \\
7\end{array}$ & $\begin{array}{l}960 \\
860 \\
966\end{array}$ & $\begin{array}{l}428 \\
350 \\
260\end{array}$ & $\begin{array}{l}15 \\
21 \\
19\end{array}$ \\
\hline \multirow{3}{*}{$\begin{array}{l}\text { Aldolase } \\
\qquad \text { units/ml }\end{array}$} & 1 & $\begin{array}{c}372 \\
\left(3.35 \times 10^{-8}\right)\end{array}$ & $\begin{array}{c}1620 \\
\left(24.40 \times 10^{-8}\right)\end{array}$ & $\begin{array}{c}1356 \\
\left(13.15 \times 10^{-8}\right)\end{array}$ & $\begin{array}{c}720 \\
\left(5.50 \times 10^{-8}\right)\end{array}$ \\
\hline & 2 & $\begin{array}{c}372 \\
\left(2.96 \times 10^{-8}\right)\end{array}$ & $\begin{array}{c}1380 \\
\left(16.85 \times 10^{-8}\right)\end{array}$ & $\begin{array}{c}1044 \\
\left(9.70 \times 10^{-8}\right)\end{array}$ & $\begin{array}{c}660 \\
\left(5.54 \times 10^{-8}\right)\end{array}$ \\
\hline & 3 & $\begin{array}{c}348 \\
\left(2.23 \times 10^{-8}\right)\end{array}$ & $\left(24.00 \times 10^{-8}\right)$ & $\begin{array}{c}1140 \\
\left(9 \cdot 05 \times 10^{-8}\right)\end{array}$ & $\begin{array}{c}660 \\
\left(4.56 \times 10^{-8}\right)\end{array}$ \\
\hline \multirow{3}{*}{$\begin{array}{l}\text { LD } \\
\text { units } / \mathrm{ml}\end{array}$} & 1 & $\begin{array}{c}2.05 \times 10^{4} \\
\left(1.81 \times 10^{-6}\right)\end{array}$ & $\begin{array}{c}4.16 \times 10^{4} \\
\left(6.26 \times 10^{-6}\right)\end{array}$ & $\begin{array}{c}3.05 \times 10^{4} \\
\left(2.97 \times 10^{-6}\right)\end{array}$ & $\begin{array}{c}2.08 \times 10^{4} \\
\left(1.64 \times 10^{-6}\right)\end{array}$ \\
\hline & 2 & $\begin{array}{c}2.17 \times 10^{4} \\
\left(1.73 \times 10^{-6}\right)\end{array}$ & $\begin{array}{r}4.29 \times 10^{4} \\
\left(5.20 \times 10^{-6}\right)\end{array}$ & $\begin{array}{c}2.88 \times 10^{4} \\
\left(2.67 \times 10^{-6}\right)\end{array}$ & $\begin{array}{c}2.35 \times 10^{4} \\
\left(1.98 \times 10^{-6}\right)\end{array}$ \\
\hline & 3 & $\begin{array}{c}1.98 \times 10^{4} \\
\left(1.27 \times 10^{-6}\right)\end{array}$ & $\begin{array}{c}3.98 \times 10^{4} \\
\left(6.35 \times 10^{-6}\right)\end{array}$ & $\begin{array}{r}2.76 \times 10^{4} \\
\left(2.19 \times 10^{-6}\right)\end{array}$ & $\begin{array}{c}1.80 \times 10^{4} \\
\left(1.37 \times 10^{-6}\right)\end{array}$ \\
\hline \multirow{3}{*}{$\begin{array}{l}\text { G6PD } \\
\text { units } / \mathrm{ml}\end{array}$} & 1 & $\left(1.65 \times 10^{-10}\right)$ & $\begin{array}{c}5.90 \\
\left(8.90 \times 10^{-10}\right)\end{array}$ & $\begin{array}{c}5.34 \\
\left(5.19 \times 10^{-10}\right)\end{array}$ & $\begin{array}{c}2.84 \\
\left(2.24 \times 10^{-10}\right)\end{array}$ \\
\hline & 2 & $\left(1.97 \times 10^{-10}\right)$ & $\begin{array}{c}5.50 \\
\left(6.66 \times 10^{-10}\right)\end{array}$ & $\begin{array}{c}5.22 \\
\left(4.83 \times 10^{-10}\right)\end{array}$ & $\begin{array}{c}2.84 \\
\left(2.08 \times 10^{-10}\right)\end{array}$ \\
\hline & 3 & $\left.\begin{array}{c}2.64 \\
\left(1.69 \times 10^{-10}\right.\end{array}\right)$ & $\begin{array}{c}6.74 \\
\left(10.80 \times 10^{-10}\right)\end{array}$ & $\begin{array}{c}5.15 \\
\left(4.07 \times 10^{-10}\right)\end{array}$ & $\begin{array}{c}3.02 \\
\left(2.30 \times 10^{-10}\right)\end{array}$ \\
\hline \multirow{3}{*}{ GSH } & 1 & $\begin{array}{c}83.5 \\
\left(0.075 \times 10^{-8}\right)\end{array}$ & $\begin{array}{c}166.0 \\
\left(0.250 \times 10^{-9}\right)\end{array}$ & $\begin{array}{c}128.0 \\
\left(0.130 \times 10^{-9}\right)\end{array}$ & $\begin{array}{c}85.5 \\
\left(0.068 \times 10^{-9}\right)\end{array}$ \\
\hline & 2 & $\begin{array}{c}93.0 \\
\left(0.074 \times 10^{-9}\right)\end{array}$ & $\begin{array}{c}173.0 \\
\left(0.210 \times 10^{-9}\right)\end{array}$ & $\left(\begin{array}{c}118.0 \\
\left(0.110 \times 10^{-9}\right)\end{array}\right.$ & $\begin{array}{c}83.5 \\
\left(0.070 \times 10^{-9}\right)\end{array}$ \\
\hline & 3 & $\left(\begin{array}{c}124.0 \\
\left(0.079 \times 10^{-9}\right)\end{array}\right.$ & $\begin{array}{c}162.5 \\
\left(0.260 \times 10^{-9}\right)\end{array}$ & $\begin{array}{c}123.0 \\
\left(0.098 \times 10^{-8}\right)\end{array}$ & $\begin{array}{c}92.4 \\
\left(0.070 \times 10^{-9}\right)\end{array}$ \\
\hline \multirow{3}{*}{ PN } & 1 & $\left(110 \times 10^{-10}\right)$ & $\begin{array}{c}224 \\
\left(323 \times 10^{-10}\right)\end{array}$ & $\begin{array}{c}156 \\
\left(150 \times 10^{-10}\right)\end{array}$ & \\
\hline & 2 & $\begin{array}{c}166 \\
\left(132 \times 10^{-10}\right)\end{array}$ & $\begin{array}{c}188 \\
\left(227 \times 10^{-10}\right)\end{array}$ & $\begin{array}{c}188 \\
\left(175 \times 10^{-10}\right)\end{array}$ & \\
\hline & 3 & $\begin{array}{c}136 \\
\left(87 \times 10^{-10}\right)\end{array}$ & $\left(319 \times 10^{-10}\right)$ & $\left(125 \times 10^{-10}\right)$ & \\
\hline
\end{tabular}

Figures in parentheses indicate values per single red cell.

* Note I : Before the injection,

II : 2nd day after completion of the injection,

III : 5th day after completion of the injection,

IV : 14th day after completion of the injection.

than that per $\mathrm{ml}$ of red cells as was shown in Fig. 3. In the same way as in the case of $\mathrm{AD}$, the reticulocyte has approximately 4 times higher activity of $\mathrm{LD}$ than the mature erythrocyte.

The activity of G6PD in red cells increased in parallel with the dgree of reticulocytosis. The activity of G6PD per single red cell showed a steeper peak 


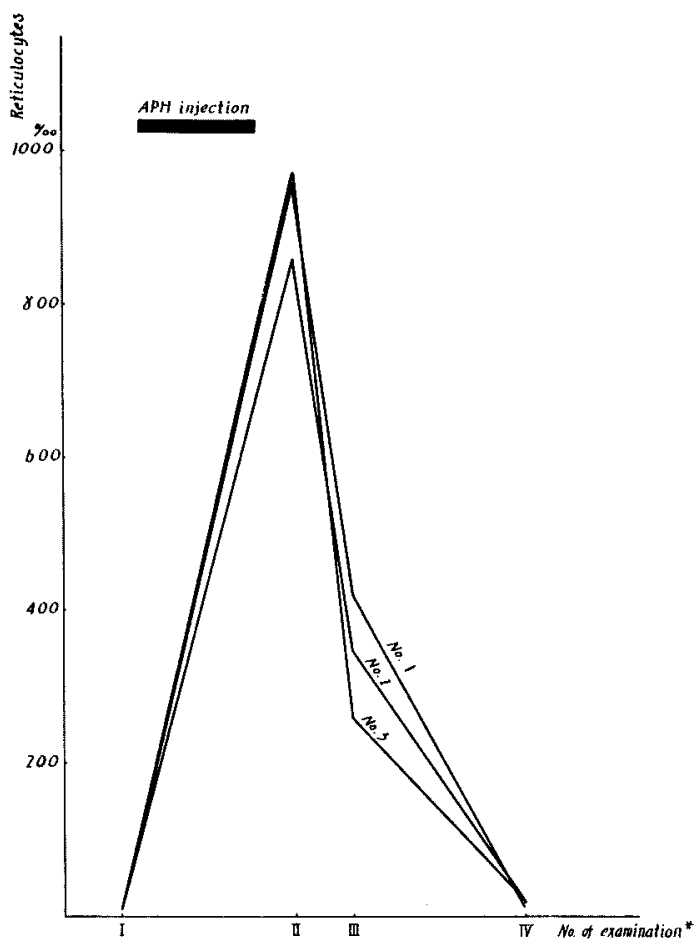

Fig. 1. Reticulocyte count in rabbits with APH injection.

* Note I: Before injection. II : 2nd day after completion of the injection.

III : 5th day after completion of the injection.

IV : 14th day after completion of the injection.

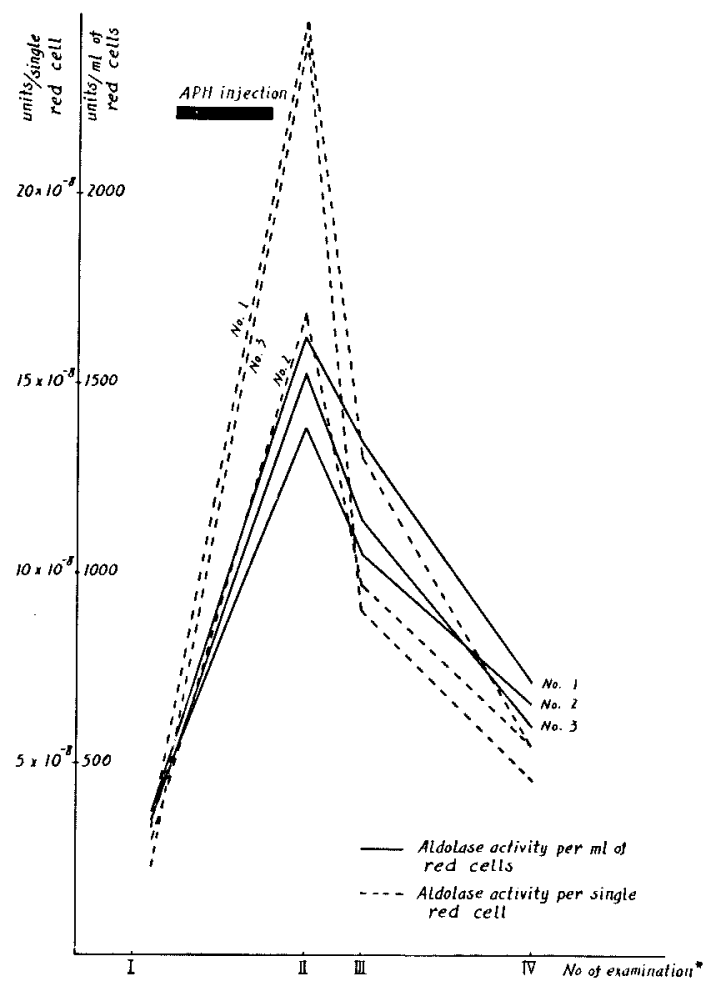

Fig. 2. Aldolase activity in red cells.

* Note : Cf. note in Fig. 1. 


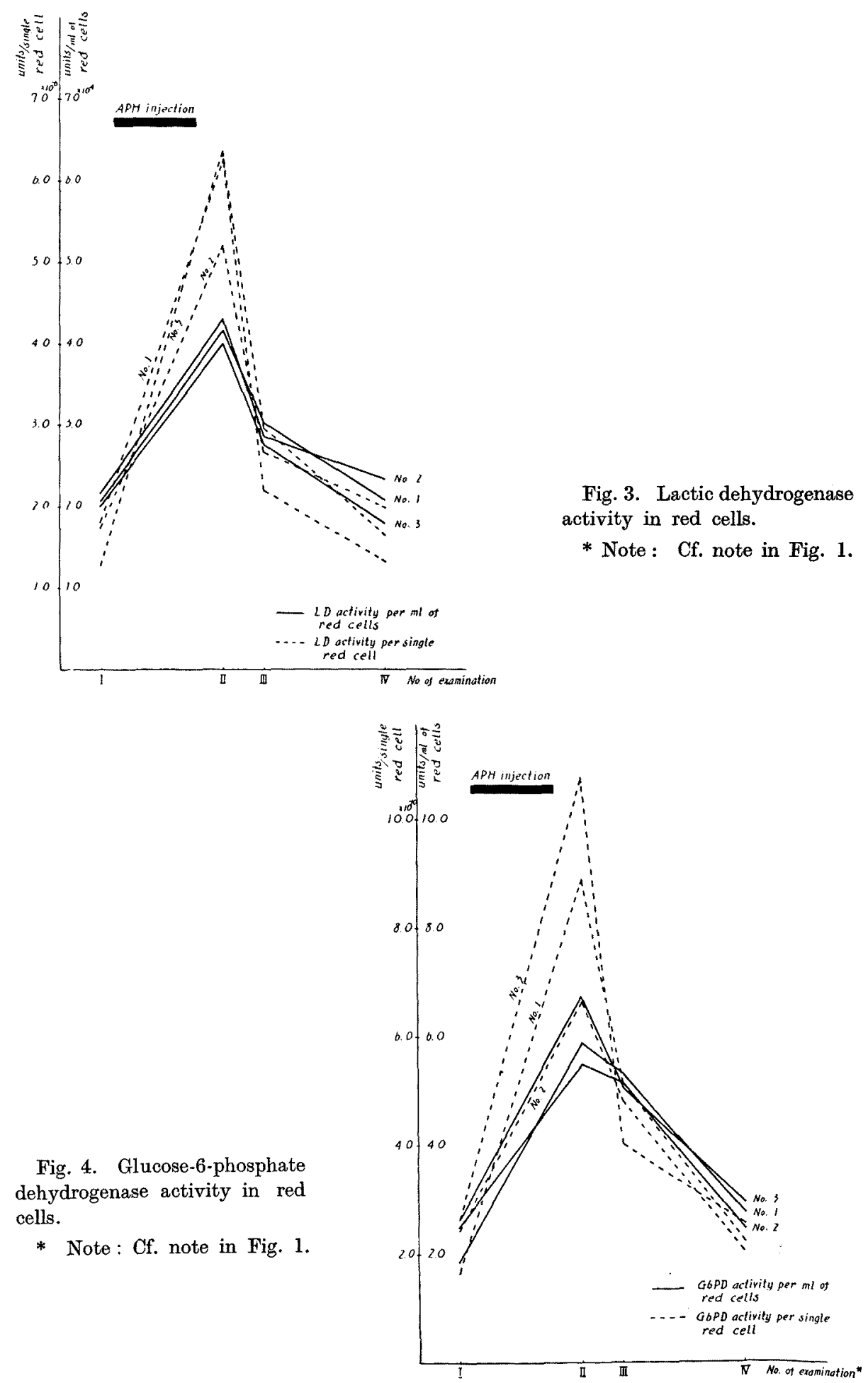


than that per $\mathrm{ml}$ of red cells as was shown in Fig. 4 . In the same way as in the case of $\mathrm{AD}$, the reticulocyte has approximately 6 times higher activity of G6PD than the mature erythrocyte.

The content of GSH in red cells increased in parallel with the degree of reticulocytosis. The content of GSH per single red cell showed a steeper peak than that per $100 \mathrm{ml}$ of red cells as was shown in Fig. 5. In the same way as in the case of $\mathrm{AD}$, the reticulocyte has approximately 3 times greater content of GSH than the mature erythrocyte.

The content of $\mathrm{PN}$ in red cells increased in parallel with the dgree of reticulocytosis. The content of PN per single red cell showed a steeper peak than that per ml of red cells as was shown in Fig. 6. In the same way as in the case of $\mathrm{AD}$, the reticulocyte has approximately 3 times greater content of $\mathrm{PN}$ than the mature erythrocyte.

The glucose uptake test (cf. Fig. 7) revealed that the utilization of glucose by the blood with reticulocytosis (over 900\%) was remarkably increased as compared with that by the blood without reticulocytosis (below 20\%). The

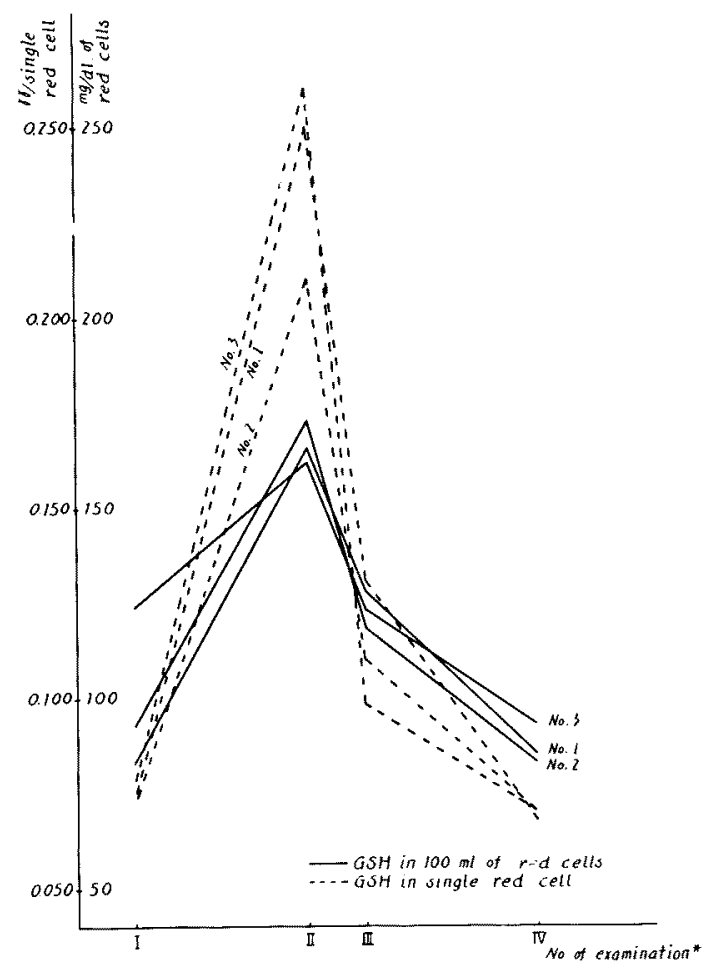

Fig. 5. Reduced glutathione content in red cells.

* Note: Cf. note in Fig. 1. 


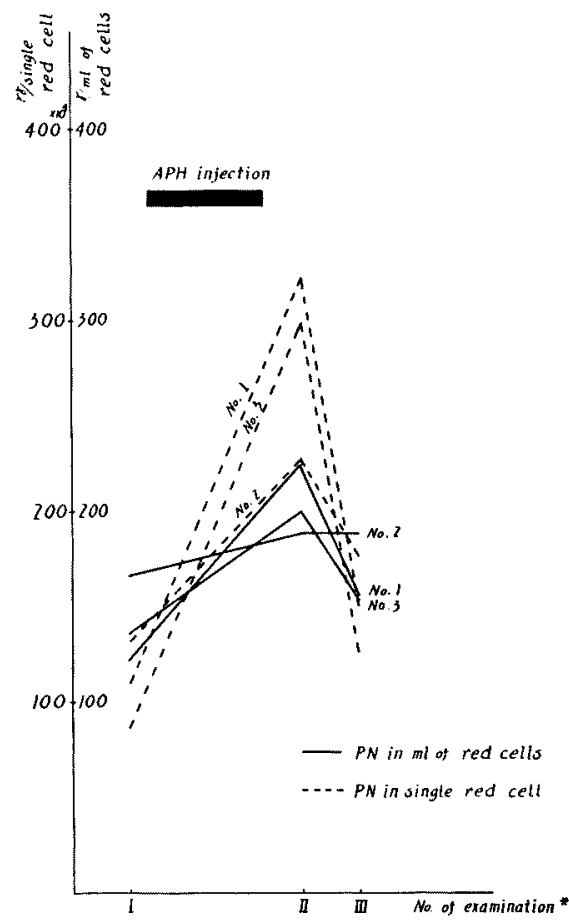

Fig. 6. Pyridine nucleotide content in red cells.

* Note: Cf. note in Fig. 1.

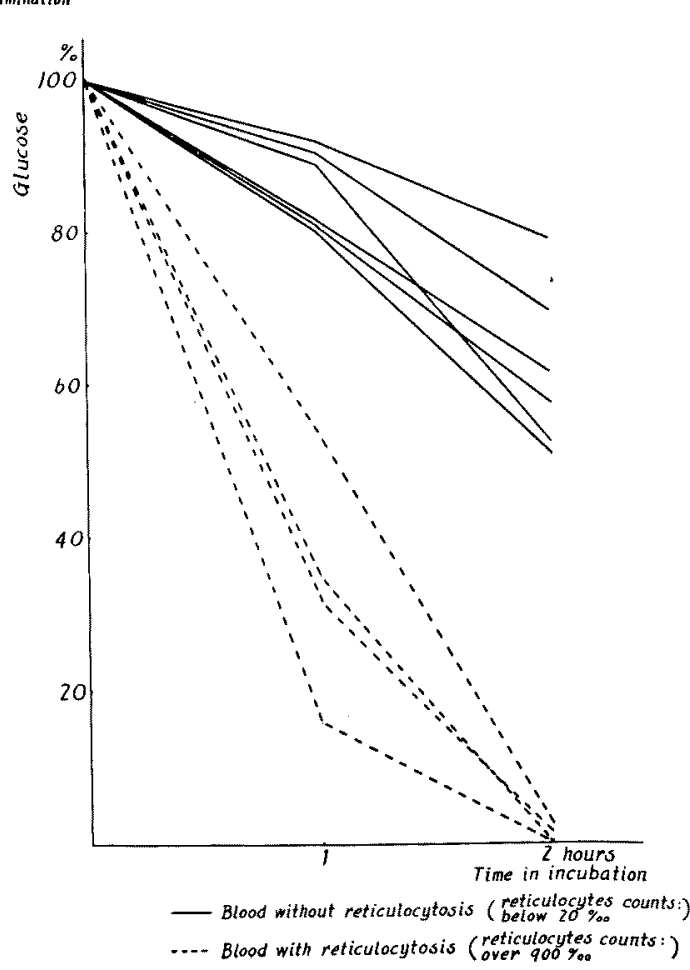

Fig. 7. Glucose uptake test by red cells. 
former blood utilized glucose in the mixture almost completely during the incubation for two hours while the latter blood utilized only 20 to $50 \%$ of glucose. These results indicate that the utilization of glucose is far greater in the reticulocyte than in the mature erythrocyte.

\section{DISCUSSION}

It has been known that the reticulocyte is different from the mature erythrocyte not only in morphological features? but also in metabolism. The reticulocyte has an active aerobic metabolism ${ }^{8 / 9)}$ by way of the tricarboxylic-acid system while the mature erythrocyte shows insignificant respiratory activity ${ }^{10}$ ) because of absence of the system. According to Rubinstein, ${ }^{10)}$ the enzymes involved in the TCA cycle such as fumarase, succinic dehydrogenase and aconitase are present in the reticulocyte but either absent or much less active in the mature erythrocyte, while G6PD and LD have approximately the same degree of activity in both types of cells. Kanai11' reported that the activity of G6PD is approximately four times higher in the reticulocyte than in the mature erythrocyte. Our results showed that the reticulocyte have about 8 to 10 times higher activity of $\mathrm{AD}$, about 4 times higher activity of $\mathrm{LD}$, and about 6 times higher activity of G6PD as compared with the mature erythrocyte. Furthermore, it was found, as a result of the glucose uptake test, that the utilization of glucose is far greater in the reticulocyte than in the mature erythrocyte.

The higher activity of $\mathrm{AD}$ and of $\mathrm{LD}$ in the reticulocyte as compared with that in the mature erythrocyte (cf. Figs. 2 and 3) suggests that glycolysis in the Embden-Meyerhof pathway may be more active in the former cell than in the latter. The higher activity of G6PD in the reticulocyte as compared with that in the mature erythrocyte suggests that the oxidative process of glucose in the pentose phosphate system also may be more active in the former cell than in the latter. It is, therefore, reasonable to presume that such a higher activity in the Embden-Meyerhof pathway and in the pentose phosphate pathway may be responsible for the increased utilization of glucose in the reticulocyte.

Our results showed that the contents of GSH and of PN were greater in the reticulocyte than in the mature erythrocyte. These results appear also to favor the concept that the reticulocyte has more active metabolism of glucose as compared with the mature erythrocyte. Because both GSH and PN - the former as an activator for SH-enzymes and the latter as a coenzyme of various dehydrogenases - play an important part in metabolism of glucose.

In case of evaluating the activity of the enzymes above quoted in red cells from the patients in the clinical field, an attention should be paid to the degree of reticulocytosis. Actually the enzymes such as AD, LD and G6PD in red cells have shown in our own investigation often high activity in case of anemia. This is probably due not to an elevation of activity of the enzymes in the mature 
erythrocyte but to a reticulocytosis caused by anemia.

\section{SUMMARY}

A remarkable reticulocytosis was induced in rabbits by the injection of acetylphenylhydrazine. The comparison between the mature erythrocyte and the reticulocyte was made in the activities of the enzymes including aldolase, lactic dehydrogenase and glucose-6-phosphate dehydrogenase and in the contents of reduced glutathione and of pyridine nucleotide.

1) Aldolase: The reticulocyte has approximately 8 to 10 times higher activity than the mature erythrocyte.

2) Lactic dehydrogenase: The reticulocyte has approximately 4 times higher activity than the mature erythrocyte.

3) Glucose-6-phosphate dehydrogenase: The reticulocyte has approximately 6 times higher activity than the mature erythrocyte.

4) Reduced glutathione: The reticulocyte has approximately 3 times higher content than the mature erythrocyte.

5) Pyridine nucleotide: The reticulocyte has approximately 3 times higher content than the mature erythrocyte.

6) The utilization of glucose by the reticulocyte is far greater as compared with that by the mature erythrocyte.

These results suggest that the reticulocyte has more active metabolism of glucose through the Embden-Meyerhof pathway and the pentose phosphate pathway, as compared with the mature erythrocyte.

\section{References}

1) Sibley, J.A. \& Lehninger, A., J. Biol. Chem., 1949, 177, 859.

2) Hill, B.R. et al., Cancer Res., 1956, 16, 460.

3) Zinkham, W.H. et al., Bull. Johns Hopkins Hosp., 1958, 102, 169.

4) Grunert, R.R. \& Phillips, P.H., Arch. Biochem., 1951, 30, 217.

5) Tada, K \& Fujiwara, T., Rinshoshoniigaku (Jap.), 1961, 9, 28.

6) Levitas, N. et al., J. Biol. Chem., 1947, 167, 169.

7) Tada, K. et al., Studies on the Reticulocyte, in press in Nihon Shonikagakkaizasshi (Jap.).

8) Warburg, O., Z. Physiol. Chem., 1909, 59, 112.

9) Wright, G.P., J. Gen. Physiol., 1930, 14, 201.

10) Rubinstein, D. et al., Canad. J. Biochem. \& Physiol., 1956, 34, 222.

11) Kanai, M. et al., Nippon Ketsuekigakkaizasshi (Jap.), 1960, 23, No. 3-Supple., 229. 